\title{
CODEX, ROLL, AND LIBRARIES IN OXYRHYNCHUS ${ }^{1}$
}

\author{
Don C. Barker
}

\begin{abstract}
Summary
The fragmented discards of a library from the ancient city of Oxyrhynchus in middle Egypt provide us with an excellent 'sample' to conduct a comparative analysis with the contemporary Christian books from the same city. Both the secular and the Christian books in general share common features except for their construction: the library books are rolls whereas the Christian books are in the codex format. What led the Christians to choose this 'new technology'? Could it be that the driving reason was the protection of the contents against tampering?
\end{abstract}

\section{Introduction}

The ancient city of Oxyrhynchus is situated some 300 kilometres south of Alexandria. In the Roman period it was the administrative centre for the Oxyrhynchite Nome. ${ }^{2}$ From the large number of literary papyri finds and the iconography it appears that Oxyrhynchus in the GrecoRoman period was a thoroughly Hellenised city. ${ }^{3}$ In later antiquity it

1 This paper is an outcome of a MURDG grant from Macquarie University that was awarded to Dr D. Barker and Professor A. Nobbs to undertake a palaeographical and codicological comparison of literary and Christian papyri from Oxyrhynchus and a 2005 British Academy of Humanities grant awarded to Professor Larry Hurtado, University of Edinburgh.

2 E. G. Turner, 'Roman Oxyrhynchus', Journal of Egyptian Archaeology 38 (1952): 78-87 stresses the importance of Oxyrhynchus within the province of Egypt and notes that the phrase, $\lambda \propto \mu \pi \rho \grave{~ k \alpha i ̀ ~ \lambda \alpha \mu т р о т \alpha ́ t \eta, ~ ' i l l u s t r i o u s ~ a n d ~ m o s t ~ i l l u s t r i o u s ' ~ w a s ~}$ appended to the city's official title in AD 272. For a history of Oxyrhynchus see J. Krüger, Oxyrhynchos in der Kaiserzeit: Studien zur Topographie und Literaturrezeption (Europäische Hochschulschriften 3.441; Frankfurt: Lang, 1990).

3 R. Alston, The City in Roman and Byzantine Egypt (Cambridge: CUP, 2002): 268. For an example of a Greek Oxyrhynchite's disdainful attitude towards the 'uncivilised' native Egyptians, see P.Oxy. 1681 (III). For recent topographical studies of 
was famous for its many churches and monasteries. ${ }^{4}$ From mainly sixth and seventh century documentary evidence it has been estimated that there could have been about forty-three churches situated in Oxyrhynchus. ${ }^{5}$ The estimates for the population of the city vary from about 12,000 to $25,000 .^{6}$

Grenfell and Hunt came to the site of ancient Oxyrhynchus to search for papyri in 1897. In their excavation report of 1906 they mention that they unearthed the discards of two libraries. ${ }^{7}$ P. W. Comfort maintains that we can ascertain from the information Grenfell and Hunt provided in this excavation report and in the forewords to volumes 513 of the Oxyrhynchus Papyri that New Testament books were found with classical books in the discards of these two libraries. Comfort makes the claim, without going into detail as to how he arrived at his conclusion, that $\mathfrak{P}^{15 / 16}$ (P.Oxy. 1008/1009), $\mathfrak{P}^{28}$ (P.Oxy. 1596), $\mathfrak{P}^{29}$ (P.Oxy. 1597), and $\Re^{30}$ (P.Oxy. 1598), came from the first library and that $\mathfrak{P}^{17}$ (P.Oxy. 1078), $\mathfrak{P}^{18}$ (P.Oxy. 1079), $\mathfrak{P}^{20}$ (P.Oxy. 1117), $\mathfrak{P}^{21}$ (P.Oxy. 1227), $\mathfrak{P}^{22}$ (P.Oxy. 1228), $\mathfrak{P}^{23}$ (P.Oxy. 1229), $\mathfrak{P}^{24}$ (P.Oxy. 1230), and $\mathfrak{P}^{27}$ (P.Oxy. 1355), came from the second library. However, as we shall see, a close reading of the 1905/6 report and the prefaces of volumes 5-13 reveal that the libraries included only classical works and not New Testament books. ${ }^{8}$

Oxyrhynchus see J. Padró et.al., 'Fouilles archéologiques à Oxyrhynchos. 1992-1994' in Proceedings of the Seventh International Congress of Egyptologists (ed. C. J. Eyre; OLA 82; Leuven: Peeters, 1998): 823-28 and J. Krüger, Oxyrhynchos in der Kaiserzeit, who provides a map of Oxyrhynchus in the Roman period.

4 When Rufinus visted Oxyrhynchus (c. 370s), he described the city as a city filled with monks and monasteries and twelve churches, Rufinus, $H M, 5$.

5 R. Alston, The City in Roman and Byzantine Egypt: 294-296.

6 The various estimates for the population of Oxyrhynchus have been based on the estimated number who received the corn dole and the estimated number of houses in the city, see Alston, The City in Roman and Byzantine Egypt: 331-34. I. F. Fikham, Oksirinkh: Gorod papirusov, (Moscow, 1976), calculates the population to be c.15,000-25,000. The variations demonstrate the difficulty in determining the population numbers not only of Oxyrhynchus but the other villages and towns in Egypt.

7 B. P Grenfell and A. S. Hunt, 'Excavations at Oxyrhynchus', Egyptian Exploration Fund: Archaeological Report 1905-1906 (London: Egypt Exploration Fund, 1906): $10,12$.

8 P. W. Comfort, The Quest for the Original Text of the New Testament (Grand Rapids: Baker, 1992): 62-64. I have learnt that Comfort has now acknowledged that this claim is incorrect and will be acknowledged in the forthcoming re-edition of the The Quest. 


\section{The Rubbish Mounds}

In their pursuit for papyri Grenfell and Hunt failed, as did most excavators of the time, to write detailed notes of the find spots of the individual papyrus manuscripts. ${ }^{9}$ However, those find spots can be determined sometimes from the general reports that Grenfell and Hunt made to the Egyptian Exploration Fund and from the introductions that they wrote for The Oxyrhynchus Papyri, vols. 5-13. The 1905/6 season at Oxyrhynchus entailed fourteen weeks of excavations. In their 1906 report, Grenfell and Hunt mention that they came across a number of mounds that yielded literary and documentary texts. ${ }^{10}$ The first mound $\left(\mathrm{M}^{1}\right)^{11}$ was excavated in December 1905 and according to Grenfell and Hunt it was a small mound yielding few papyri that were of slight interest ranging from the third century to the fifth century A.D. The second mound $\left(\mathrm{M}^{2}\right)$ contained papyri mainly from the fifth century. A high proportion were literary papyri - both classical and theological ranging from the fourth to the sixth century and, according to Grenfell and Hunt, nearly always in book form. ${ }^{12}$ Of all the theological texts that were found, Grenfell and Hunt identify only one manuscript - a 'lost gospel' - as coming from this mound. ${ }^{13}$ The third mound $\left(\mathrm{M}^{3}\right)$ that they excavated contained fourth or fifth century A.D. papyri to a depth of ten feet and below this strata papyri were found from the late Ptolemaic and very early Roman period. ${ }^{14}$ They then report that they found a long narrow range of mounds $\left(\mathrm{M}^{4+}\right)$ that were rich in literary papyri. ${ }^{15}$ This was excavated in January, 1906. The eastern part of these mounds contained papyri from the second and third centuries and the western part mainly from the fourth or fifth century with earlier layers of papyri underneath. It is from these mounds that Grenfell and Hunt found what they described as two scholars' libraries. The first library was found on 13th January, 1906, six feet from the surface and consisted of a basketful of discarded broken literary papyrus rolls belonging to the second or third century which, according to Grenfell and Hunt, were

9 For a discussion on the lack of scientific care in the excavation of papyri at Oxyrhynchus, see Turner, 'Roman Oxyrhynchus': 80.

10 Grenfell and Hunt, 'Excavations at Oxyrhynchus': 10-14.

11 The numbering of the mounds is mine.

12 Grenfell and Hunt, 'Excavations at Oxyrhynchus': 9.

13 Grenfell and Hunt, 'Excavations at Oxyrhynchus': 9.

14 Grenfell and Hunt 'Excavations at Oxyrhynchus': 9, 10.

15 Grenfell and Hunt 'Excavations at Oxyrhynchus': 10. 
thrown away in the third century. ${ }^{16}$ The discards from a second library were found in a different mound. In this mound, a strata 10 to 15 feet deep contained papyrus that belonged to the fourth to fifth century A.D. Beneath this layer, papyri from the Roman period were found. The library papyri were found about eight feet from the surface in a thin layer of many square yards and numbered over thirty manuscripts. ${ }^{17}$ Grenfell and Hunt finally report of another find of literary papyri in the same mound in which the second library was found. They described this find as 'with one exception the largest find of papyri that has yet occurred at Oxyrhynchus'. ${ }^{18}$ The majority of the manuscripts consisted of first to second century documents but also many literary documents.

The evidence gained from the report can be summarised as follows:

\begin{tabular}{|c|c|c|c|c|}
\hline $\begin{array}{l}\text { Mound } \\
\text { No }\end{array}$ & $\begin{array}{c}\text { Date of } \\
\text { excavation }\end{array}$ & $\begin{array}{l}\text { Type of papyri } \\
\text { found }\end{array}$ & Date of Papyri & Comments \\
\hline 1 & Dec. 1905 & $\begin{array}{l}\text { Few papyri of slight } \\
\text { interest. }\end{array}$ & III-V & Small mound \\
\hline 2 & Dec. 1905 & $\begin{array}{l}\text { High proportion of } \\
\text { both theological and } \\
\text { classical }\end{array}$ & $\begin{array}{l}\text { IV-VI } \\
\text { Most V }\end{array}$ & $\begin{array}{l}\text { Nearly always in } \\
\text { book form } \\
\text { Lost gospel- vellum }\end{array}$ \\
\hline 3 & Dec. 1905 & & $\begin{array}{l}\text { Top layer IV or V } \\
\text { Below : late Ptolemaic, } \\
\text { early Roman }\end{array}$ & \\
\hline $4+$ & Jan. 1906 & $\begin{array}{l}\text { Literary fragments - } \\
\text { numerous }\end{array}$ & $\begin{array}{l}\text { Eastern section - II, III } \\
\text { Western section - IV,V } \\
\text { (mainly) }\end{array}$ & $\begin{array}{l}\text { 'The mounds were } \\
\text { rich in papyri' }\end{array}$ \\
\hline$-\mathrm{a}$ & $13 / 1 / 06$ & First classical library & $\begin{array}{l}\text { Early layers underneath. } \\
\text { II or III }\end{array}$ & $\begin{array}{l}\text { A basket full of nine } \\
\text { classical works from } \\
\text { a scholar's library- }\end{array}$ \\
\hline$-b$ & $\begin{array}{l}\text { Remainder of } \\
1906\end{array}$ & $\begin{array}{l}\text { Second classical } \\
\text { library }\end{array}$ & $\begin{array}{l}\text { IV - V layers }(10-15 \mathrm{ft} \text { in } \\
\text { depth) } \\
\text { Beneath this a Roman } \\
\text { strata to } 30 \mathrm{ft} .\end{array}$ & $\begin{array}{l}\text { More than twice the } \\
\text { size of first library - } \\
\text { over } 30 \text { MSS. Found } \\
8 \mathrm{ft} \text { down. }\end{array}$ \\
\hline$-\mathrm{c}$ & $\begin{array}{l}\text { End of the } \\
\text { season of } 1906\end{array}$ & $\begin{array}{l}\text { Documentary and } \\
\text { literary }\end{array}$ & $\begin{array}{l}\text { The bulk are I - II } \\
\text { Near surface IV }\end{array}$ & $\begin{array}{l}\text { 'The largest find of } \\
\text { papyri so far' }\end{array}$ \\
\hline
\end{tabular}

16 Grenfell and Hunt do not give reasons for this date. Perhaps it was because the library papyri were found in strata that contained third century papyri.

17 Grenfell and Hunt conclude that they were discarded in the fifth century because of the date of the documents found below the library papyri.

18 Grenfell and Hunt, 'Excavations at Oxyrhynchus': 13. 


\section{The Discards}

My interest, for the purpose of a comparative analysis with the New Testament books, is with the contents of the discards of the first library, as we are able to trace the entire contents of this find, in contrast to the second library. ${ }^{19}$ The introductions to the above-mentioned volumes, as well as individual introductions to some of the papyri, provide information regarding the find spots for some of the papyri and the contents of the first library. In the preface of Oxyrhynchus Papyri, vol. 5, Grenfell and Hunt mention that this volume contains the large finds of Jan. 13, 1906. The four long classical papyri are literary fragments from the first library $\left(\mathrm{M}^{4+\mathrm{a}}\right)$ 841, Pindar, Paeans, 842 Theopompus (or Cratippus), Hellenica III. Extant Classical Texts, 843, Plato, Symposium and $\mathbf{8 4 4}$ Isocrates, Panegyricus. ${ }^{20}$ They also note that the vellum fragment of a lost gospel (840) which was unearthed in a different mound in December $1905\left(\mathrm{M}^{1}\right)$, is published in volume 5. In the introduction to volume 6 they note that the two long classical texts of the Hypsipyle of Euripides, $\mathbf{8 5 2}$ and the commentary on Thucydides 858 formed part of the large literary find of 13/1/1906 $\left(\mathrm{M}^{4+a}\right)$. The other literary papyri were found during the same season $\left(\mathrm{M}^{1}, \mathrm{M}^{2}, \mathrm{M}^{3} \&\right.$ $\mathrm{M}^{4+}$ ) and some in 1897 or 1902 . The great majority of the papyri of volume 7 including the chief literary pieces were discovered in the season of 1905-6 $\left(\mathrm{M}^{1}, \mathrm{M}^{2}, \mathrm{M}^{3} \& \mathrm{M}^{4+}\right)$; a few come from the finds of the years 1903 and 1904. Grenfell and Hunt in the introduction to volume 8 mention that Meliambi of Cercidas, $\mathbf{1 0 8 2}$ and the fragments of an anonymous Satyric drama, $\mathbf{1 0 8 3}$ plus 1091-2 are derived from the second literary find in $1906\left(\mathrm{M}^{4+\mathrm{b}}\right) .^{21} \mathrm{In}$ the preface of volume 10 they mention that the new literary pieces 1231 and 1233-5 come from the large literary find of $1906\left(\mathrm{M}^{4+}\right)$ with some small additions from the work of the next season. The remainder with the extant and non-literary

\footnotetext{
19 See Grenfell's comments to the preface of P.Oxy. vol. 13 where he notes that with the publication of volume 13 all the finds from the first library have now been published. According to Grenfell and Hunt in their 1906 report the contents of the finds from the second library were twice as large as the first ('Excavations at Oxyrhynchus': 12). However when Grenfell and Hunt retired from being editors of the Oxyrhynchus volumes, subsequent editors fail to mention the find spot of any literary papyri that they edited, therefore the majority of the papyri from the second library cannot be identified. Papyri from the second library that can be identified are: 1082, $1083,1091,1092,1359,1610,1611$, and 1360 .

20 I use bold numbers to refer to P. Oxy. material from the two libraries.

21 Grenfell and Hunt, 'Excavations at Oxyrhynchus': 12.
} 
papyri for the most part were found in 1903-04. In the preface of volume 11 Grenfell and Hunt note that Antiphon Sophistes, 1364 and Thucydides, $\mathbf{1 3 7 6}$ belong to the first of the literary finds of $1906\left(\mathrm{M}^{4+a}\right)$ and the lyric pieces and one of the Hesoid fragments, 1359 to the second $\left(\mathrm{M}^{4+\mathrm{b}}\right)$. The invocation of Isis, $\mathbf{1 3 8 0}$ and the praise of ImouthesAsclepius, 1381 were found in 1903 whilst the rest were found chiefly in $1905 / 6\left(\mathrm{M}^{1}, \mathrm{M}^{2}, \mathrm{M}^{3} \& \mathrm{M}^{4+}\right)$. Grenfell notes in the preface of volume 13 that the papyri of Lysias 1606, Hyperides, 1607 Aeschines Socraticus 1608 and the oration on the cult of a Roman Emperor 1612 belong to the first of the three large literary finds of 1905/6 season which produced numbers 841-4 $\left(\mathrm{M}^{4+\mathrm{a}}\right)$. Ephorus, 1610 and the literary criticism of Herodotus 1611 belong to the second find $\left(\mathrm{M}^{3+}\right.$ find 2, library 2). Most of the other texts were found in early part of the same season. $\left(\mathrm{M}^{1}, \mathrm{M}^{2}\right)$. Finally in the introduction to P.Oxy. 1606, Grenfell mentions that along with $1606 ; \mathbf{1 6 0 7 , 1 6 0 8}$ and 1612 formed part of the first of the finds of literary papyri $\left(\mathrm{M}^{4+\mathrm{a}}\right)$, which also produced 841-2, 852-3, 1012, 1016-17, 1364 and 1376.

From the above information we are able to ascertain that the following books belong to the first library.

841 Pindar, Paeans

842 Theopompus (or Cratippus), Hellenica III. Extant Classical Texts

843 Plato, Symposium

844 Isocrates Panegyricus

852 Euripides, Hypsiple

853 Commentary on Thucydides II

858 Oration against Demosthenes

1012 Treatise on Literary Composition

1016 Plato, Phaedrus

1017 Plato, Phaedrus

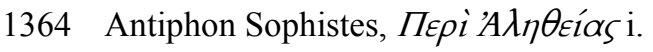

1376 Thucydides vii

1606 Lysias, pros Hippothersen, Against Theomnestus,

1607 Hyperides (?), For Lycophron

1608 Aeschines Socraticus, Alcibiades

1612 Oration on the Cult of Caesar

From this analysis of Grenfell and Hunt's excavation report of 1906 and the introductions to volumes 5-13 of The Oxyrhynchus Papyri, it is evident that no New Testament manuscripts were found with the library finds of 1906, which is why Grenfell and Hunt allude to these 
libraries as classical libraries. ${ }^{22}$ Presumably the New Testament papyri were found either in the literary finds of 1905 or in the larger finds of literary papyri in 1906 or even perhaps in the earlier finds of previous seasons. ${ }^{23}$

\section{The Social Context}

Who owned the library from which these classical books were discarded presumably because of wear and tear? Cribiore notes that it is difficult to distinguish books used for teaching purposes from those used by the educated individuals; however some books, either in the manner in which they were produced or in their content distinguish themselves as books used for instructional purposes. ${ }^{24}$ With regard to the contents of the first library we can observe that, Pindar's Paeans (841) is clearly an educationalist's tool. It is written in short columns (c. $11.5 \mathrm{~cm}$.) of fifteen or sixteen lines. A very wide margin (c. 14-15 $\mathrm{cm}$.) was left between the columns for explanatory notes, which are written in a cursive style by a different hand. The lines of the main text were placed wide apart, perhaps as Grenfell suggests, for interlinear comments. We may also note: 1012, which contains a considerable diversity of topics: an analysis of the characteristics of Lysias; observations on systems of ethics; a collection of instances of omissions and suppression of names or facts in various prose writers; criticism of the orators' for belittling the achievements of Philip; censure of the diction of Xenophon; a list of words having double meanings distinguished by different accents and 853, a commentary on Thucydides II. The plentiful use of accentuation and punctuation in the texts also suggests an educational context. ${ }^{25}$ As to what educational

22 Grenfell and Hunt, 'Excavations at Oxyrhynchus': 12.

23 For example Grenfell and Hunt note in the preface to P.Oxy. vol. 6 that some of that literary papyri were found in 1897 and 1902 as well as the literary finds of 1905/6; similarly in the preface of P.Oxy. vol. 7 they note that note that a few of the literary papyri were from the finds of 1903 and 1904 and in P.Oxy. vol. 10 it is noted in the preface that some of the literary papyri came from the finds of 1903/4.

24 R. Cribiore, Writing, Teachers, and Students in Graeco-Roman Egypt (ASP 36; Atlanta: Scholars, 1996): 138, notes that books used by learners 'exhibit particular characteristics in the presentation of the material or features intended to facilitate reading or...the student who read them or the teacher who used them to prepare his class left marks and annotations'.

25 See Cribiore, Writing, Teachers, and Students: 141 for the use of accentuation and punctuation in educational books. 
context they belonged, there are a number of possibilities. Some topographical information for the city can be gleaned from early fourth century documents, P.Oxy. 43 and P.Oxy. 4441. The verso of P.Oxy. 43 lists the guards and their stations. In Column 4 it mentions a street that led to the gymnasium and another which led to the theatre. P. Oxy. 4441 is a list of buildings that are in need of repair. In the list a library/record house $\left(\beta 1 \beta \lambda_{10} \theta \eta \dot{k} \eta\right)$ and a school and schoolmaster are mentioned. The $\beta 1 \beta \lambda_{10} \theta \eta \dot{k} \eta$ is most probably the record house for the Oxyrhynchite nome rather than a public library. ${ }^{26}$ It may be that the library belonged to a local Oxyrhynchus teacher connected to the school or to the school itself, however if this school was only involved in primary education it seems unlikely that the books would have been associated with the school as they are 'high level' classical literature used in higher education. ${ }^{27}$ Secondary instruction was offered to pupils at Oxyrhynchus and even perhaps the study of rhetoric. Personal teachers were also used to instruct upper class children as evidenced by P.Oxy. 930, a letter written in the Roman period by a mother to her son Ptolemaios. According to the letter, Ptolemaios was pursuing a secondary education in Oxyrhynchus. He was reading Book 6 of the Iliad when his instructor, an itinerant tutor, decided to depart. Gymnasiums in Egypt were the custodians of Hellenic tradition. Because of their educational influence these books may have belonged to a library associated with the gymnasium at Oxyrhynchus. ${ }^{28}$ Finally a number of Alexandrians, including professors from the museum, possessed property in the city and it may be that the library books belonged to such a person. ${ }^{29}$ We may also observe from Table 1 that the books of the first library span a period of approximately 150-200 years. This suggests that some of the books were either purchased from

26 For the word meaning 'record house' or 'registry' see P.Tebt. 389.18.

27 See Cribiore, Writing, Teachers, and Students: 143-146 for the higher stages of education and the types of books involved.

28 For the evidence of libraries in the Hellenistic period being associated with gymnasiums see L. Casson, Libraries in the Ancient World (Yale: YUP, 2002): 57-58. For gymnasiums in Egypt as places of intellectual activity and therefore presumably a place where books were held (as was the case at Athens) see Cribiore, Writing, Teachers, and Students: 34-36.

29 From the papyri Turner counted twenty-four Alexandrian citizens who owned property at Oxyrhynchus in the first three centuries ('Roman Oxyrhynchus': 85-86). Five of them held the chief municipal offices in Oxyrhynchus in the third century A.D; E. G. Turner, 'Scribes and Scholars of Oxyrhynchus' in Akten des VIII Internationalen Kongress für Papyrologie Wien 1955 (Wien: R. M. Rohrer, 1956): 141-46. 
a dealer in second hand books or the books were passed down from one generation to the next.

\section{Books - Christian and Secular}

The discards of the library discovered by Grenfell and Hunt provide us with a 'sample' to which we can pose the question, 'What palaeographical and codicological differences, if any, would the owner of this library notice between his books and contemporary Christian books?' ${ }^{30}$ Firstly the owner would notice a number of similarities. The library books 841, 842, 852, 853 and 1016 are made from recycled papyri manuscripts from a government office. This practice of reusing papyri may also be observed in the New Testament books, 657/PSI 1292 and 1079. Secondly the books in the library and the New Testament books range in quality from professionally produced deluxe editions: 1017 (library), 1780 (NT) to what appears to be privately produced books, 1016, 1612 (library), 402, 1079 (NT). ${ }^{31}$ Thirdly the sizes of the letters (c. 2-3mm) are also similar, although $\mathbf{1 7 8 0}(\mathrm{NT})$ is an exception, both in the letter height (c. $5 \mathrm{~mm}$ ) and the calligraphic nature of the lettering. The Library owner would have considered this book as an expensive deluxe copy. Both the letter size and the calligraphic nature of the hand suggest that this codex may have been used in a public reading context. Fourthly, as can be observed from table 1 and 2, there is similar variation both in the height of the papyrus sheet and the number of lines per column/page for both rolls and

\footnotetext{
30 For the purpose of this study we will make not two unreasonable assumptions: firstly that the discards from the library are representative of the entire library holdings and secondly that the books in the library are representative of all contemporary secular books that were produced for libraries and at Oxyrhynchus. The question of whether there was a style that was peculiar to Christian books has been raised by various scholars. E. G. Turner, The Typology of the Early Codex (Hanley Foundation Series 18; Philadelphia: University of Pennsylvania Press, 1977): 84-87 notes from his detailed research that early Christian codices tended to have fewer lines per page and fewer letters to the line than non-Christian manuscripts-which Turner attributed to the public reading of Christian texts. Other scholars have noted other peculiarities of Christian manuscripts such as the use of nomina sacra, (C. H. Roberts, Manuscript Society and Belief [London: Oxford University Press, 1977]: 26-48 or affinities with documentary texts (H. Y. Gamble, Books and Readers in The Early Christian Church [New Haven: Yale University Press, 1995]: 71). No clear answer however has been given to whether there is a peculiar Christian style.

31 See W. A. Johnson, Bookrolls and Scribes in Oxyrhynchus (Toronto: University of Toronto Press, 2004): 159-160, for a discussion on this aspect of book production.
} 
codices. Fifthly many of the books in the library have punctuation marks and accents to aid in the reading and understanding of the text. A number of the New Testament books also use reading aids such as stops and blank spaces. However the non-use of accents for New Testament books in contrast to many of the books in the library would have been noticeable to the library owner. In the library, for example, we may observe that 841, 842, 852, 1016, 1017, 1093, 1364 and 1608 use accents to aid in pronunciation. In the New Testament books, however, accents are noticeably absent. What are we to make of this? Were those who read the New Testament books, not so concerned about pronunciation? Or do we find more accents in the library books as they were used in an educational context? We must be hesitant in drawing any conclusions, as the 'sample' is very small, especially in regard to the secular literary texts. ${ }^{32}$ Furthermore we do not know the circumstances that led to the New Testament manuscripts being thrown onto the rubbish dumps. Until we have a better understanding of the why and the how, we need to proceed with caution with any conclusions based on the remains of New Testament books that we find in the rubbish dumps. ${ }^{33}$

The major difference the owner of the library books would notice is in the construction of the books; roll format for the classical library and almost all of the New Testament books in codex format for as can be seen from table 2, apart from three New Testament books, the rest of the New Testament books are in the codex format, confirming the observation made by others that, at least from the second century onwards, early Christianity embraced the codex format with enthusiasm having an almost exclusive preference for the codex form. ${ }^{34}$

32 That this is so is evident from the findings of Johnson, Bookrolls and Scribes: 185200.

33 There are at least three possibilities. (i) The New Testament fragments found on the rubbish dumps are the remains of books that were seized by the authorities in times of persecution. (ii) They are the remains of books that had been thrown out by their owners because they were worn out. (iii) They are the remains of worn out pages that had been replaced. Unlike the library remnants, some of which consist of a considerable number of fragments for the one book, showing that they had been torn up before being thrown onto the rubbish dump, it seems that the last possibility is the most likely.

34 See for instance C. H. Roberts and T. C. Skeat, The Birth of the Codex, (London: Oxford University Press for the British Academy, 1983): 38-44. We are assuming that books in the codex format have the same survival rate as a roll. 
How would the owner of the library $\mathrm{M}^{4 \mathrm{a}}$ view these Christian codices? To answer this we need to keep in mind that even though the Christian books were produced in the codex format it was not a distinctively Christian feature. S. Emmel rightly observes that the oldest extant Christian codices are no older than the oldest extant nonChristian codices (second century), which should caution us in crediting Christianity with its invention or its initial popularization. ${ }^{35}$ Initially in antiquity the codex was not recognised as a proper book but rather as a private notebook. Its origins are to be found in blocks of wood (caudex) linked together with a cord through holes drilled on one edge making, what was know in Latin, a codex. These codices were used for letters, accounts, school exercises, notes and various legal documents. Parchment and papyrus sheets came also to be used for the leaves of the codex. ${ }^{36}$ The first evidence of the use of the codex format for classical literature is found in the later part of the first century in Martial, the Roman poet who advises readers who wish to carry his poems on a journey to purchase 'those that parchment confines in small pages' (Epigr. I.2: quos artat brevibus membrana tabellis) so that they can be held in one hand. He also mentions pugillaribus membranis in the context of well-known authors' works being available in such format. By this phrase he no doubt means small parchment codices. Therefore at least by the time of Martial, booksellers were producing books in the codex format for the travelling public.

The evidence from Egypt clearly shows that in the second and third centuries classical works as well as other literary genre were being produced in the codex format (see table 3) and even though they constitute a very small percentage of books compared to the vast majority in the roll format nevertheless the codex format was beginning to be used. ${ }^{37}$ Perhaps their presence in Oxyrhynchus was due to the

35 S. Emmel, 'The Christian Book in Egypt', The Bible as Book, The Manuscript Tradition, eds.. J. Sharpe and K. Van Kampen (London: British Library \& Oak Knoll Press, 1998): 37, 38.

36 For a proposed origin of the codex, see Roberts and Skeat, The Birth of the Codex: 11-23.

37 Approximately 1150 literary papyri have been discovered in Oxyrhynchus dating from the second to the third century A.D. Of these, thirty-one are Christian codices and twenty-eight are secular (see the table below). J. van Haelst, 'Les Origines du Codex' in A. Blanchard (ed.) Les Débuts du Codex (Bibliologia 9; Turnhout: Brepols, 1989): 13-35 makes the observation that there are eighteen second century non-Christian literary manuscripts in codex form which comprise less than two percent of the total literary books that have been found in Egypt. 
travelling scholars and merchants who carried the Greek classics and other literature on their journeys to and from the city. ${ }^{38}$ Portability may also be the reason why the early Christians embraced the new technology of the codex. ${ }^{39}$ Christianity was a rapidly expanding religion that had at its centre a large body of literature that was fundamental to its catechetical purposes. To carry this literature from one centre to another in the codex format would have been an obvious choice as that format was already in use for this very purpose. ${ }^{40}$ Paul himself may have even begun this practice for it may be that the parchment codices tas membranas that are referred to in 2 Timothy 4:12 and which Paul is concerned about more than any other of his books ( $t a$ biblia) are copies of his letters he had sent to the various churches. ${ }^{41}$

The evidence from Egypt suggests that the codex format was beginning to be appreciated by the second century as a medium for reference works such as grammatical, lexical and medical books. ${ }^{42}$ The codex lends itself to this use as it facilitates the search for various topics throughout a book. However we need to be cautious in assuming awkwardness in using the roll for a culture that was very familiar with the roll format. The owner of the library may have viewed the Christian codices as the textbooks of a new philosophical school. This view of

38 Perhaps some of the professors from Alexandria who had property in Oxyrhynchus used them on their journey to and from Oxyrhynchus.

39 For a comprehensive review of the various hypotheses why the early Christians adopted the codex, see S. R. Llewelyn, 'The Development of the Codex' in New Documents Illustrating Early Christianity Volume 7 (Sydney: Macquarie University Ancient History Documentary Research Centre, 1994): 249-56. Llewelyn suggests that the Pauline letters played an important roll in acting as an impetus for the adoption of the codex format. For this same suggestion see also Gamble, Books and Readers: 6066.

40 In about the year 190 the Phrygian bishop Avircius Marcellus paid a visit to Rome. His own epitaph gives us an account of this journey in figurative language. In part he mentions that he had as his fellow traveller Paul; meaning that he had a copy of Paul's epistles which he read on his journey, F. F. Bruce, The Spreading Flame (Carlisle, Cumbria: Paternoster, 1970): 287.

41 For the meaning of tas membranas see Gamble, Books and Readers: 64. On the likelihood that Paul's letters were written in a codex format see Gamble, Books and Readers: 58-60. On the possibility of the disciples writing the sayings of Jesus down in notebooks, see A. R. Millard, Reading and Writing in the Time of Jesus (Sheffield: Academic Press, 2001): 204.

42 Gamble notes that of the seventeen second-century non-Christian codices, eleven are literary texts while six are professional manuals such as grammatical, lexical, and medical handbooks. Gamble offers the suggestion that the eleven literary texts may in fact be working copies for educational use, however there is no evidence for this and they may be purely travelling books. Gamble, Books and Readers: 65-66. 
the codices would have been further confirmed by the use of the books by appointed teachers for instructional purposes.

\section{Conclusion}

While the codex has obvious advantages, as the evidence seems to suggest, it is the almost universal preference for it amongst Christian communities that is intriguing and is made even more so when we consider that the construction of a codex requires specialty skills, such as the knowledge of how to fashion and plan quires, sew bindings, craft and attach covers. ${ }^{43}$ All this raises the possibility that a decision was taken by an authorized person or persons, which bound the churches to the codex format. Furthermore that decision must have been made very early in the dissemination of the literature as P.Ryl. 52, which may be earliest surviving text, is in codex format. Gamble argues that the format was due to the books being the manuals and textbooks of the movement and therefore they assumed the codex format like their contemporary counterparts. We may observe however, from the contents of the library, that textbooks were still being produced in the roll format. Portability and easy referencing are all reasons for preferring the codex format but even so we would still expect a good percentage of Christian books to be produced in the roll format unless there was an expectation for them to be produced as codices. From where did this expectation arise? ${ }^{44}$ Perhaps it was theologically driven, to protect orthodox books from being tampered with. It would have been very easy to add a heterodox writing or comments to a roll, which contained an orthodox book so that it appeared accepted by the orthodox. All it took was to glue more papyri to the end of the roll, whereas the codex being a self-contained unit protected its contents

43 Unfortunately the covers of the second and third century New Testament codices from Oxyrhynchus have not survived. However, covers have been found on some of the Nag Hammadi codices (c. mid IV) which reveal an elaborate system of bookbinding (see J. Robinson, 'The Construction of the Nag Hammadi Codices' in Essays on the Nag Hammadi Texts in Honour of Pahor Labib, ed. M. Krause [Leiden: E. J. Brill, 1975]: 170-190). Even if the bookbinding process was not as elaborate for the earlier codices, it would still require a much more complex procedure than the construction of a bookroll. For a discussion on the advantages and disadvantages of the codex and its production, see Johnson, Bookrolls and Scribes: 86-87.

44 As has been mentioned above, Llewellyn states that the Pauline letters were the impetus; however this does not explain why the gospels and non-Pauline literature were also produced in the codex format. 
from any such tampering. ${ }^{45}$ Of course this is all speculation; however something of such import must have been the influencing factor in the almost universal choice of the codex for Christian texts apart from the obvious advantages that the codex offers.

\section{Tables Comparing Books from Library with Contemporary NT books from Oxyrhynchus}

Table 1: First Library $\left(M^{4+a}\right)$

\begin{tabular}{|c|c|c|c|c|c|c|}
\hline $\begin{array}{l}\text { P.Oxy. } \\
\text { Siglum }\end{array}$ & $\begin{array}{l}\text { Codex } \\
\text { / Roll }\end{array}$ & $\begin{array}{c}\text { Size } \\
\operatorname{cm}(\mathbf{H})\end{array}$ & $\begin{array}{c}\text { lines } \\
\text { per col. }\end{array}$ & Hand & Punuctuation etc. & Date \\
\hline 841 & $\mathrm{R}$ & 18 & c. 15 & $\begin{array}{l}\text { Medium size neat } \\
\text { reformed documentary }\end{array}$ & $\begin{array}{l}\text { Rough breathings, } \\
\text { accents, paragraphi, high } \\
\text { stop }\end{array}$ & Early II \\
\hline 842 & $\mathrm{R}$ & $20: 9$ & 39 & $\begin{array}{l}\text { Very small neat } \\
\text { informal reformed } \\
\text { documentary }\end{array}$ & $\begin{array}{l}\text { Double dot, high stop, } \\
\text { paragraphi, accents, } \\
\text { rough breathings }\end{array}$ & Early II \\
\hline 843 & $\mathrm{R}$ & $31: 1$ & 47 & $\begin{array}{l}\text { Small well formed } \\
\text { informal documentary }\end{array}$ & Double dot, paragraphus & Early III \\
\hline 844 & $\mathrm{R}$ & $31: 1$ & 38 & Large formal round & $\begin{array}{l}\text { Paragraphi, blank space, } \\
\text { high, middle \& low stops }\end{array}$ & Early II \\
\hline 852 & $\mathrm{R}$ & $37: 1$ & $54-66$ & $\begin{array}{l}\text { Quickly written } \\
\text { reformed documentary }\end{array}$ & $\begin{array}{l}\text { Accents, rough } \\
\text { breathings, high stop }\end{array}$ & II/III \\
\hline 853 & $\mathrm{R}$ & $20: 5$ & $35-38$ & $\begin{array}{l}\text { Small and neat informal } \\
\text { round }\end{array}$ & Paragraphi & Late II \\
\hline 858 & $\mathrm{R}$ & $18+$ & $?$ & $\begin{array}{l}\text { Small sloping neat } \\
\text { informal round }\end{array}$ & ------------- & II/III \\
\hline 1012 & $\mathrm{R}$ & $33: 5$ & c. 40 & $\begin{array}{l}\text { Small Informal round } \\
\text { reformed documentary } \\
\text { hand }\end{array}$ & Paragraphi, blank space & III \\
\hline 1016 & $\mathrm{R}$ & $28+$ & 47 & Small to medium hand & $\begin{array}{l}\text { Double dots, high stop, } \\
\text { accents, comma between } \\
\text { double mutes }\end{array}$ & III \\
\hline 1017 & $\mathrm{R}$ & $27: 5$ & 34 & $\begin{array}{l}\text { Larger Rounded } \\
\text { informal capital } \\
\text { reformed documentary }\end{array}$ & $\begin{array}{l}\text { Accents, rough } \\
\text { breathings, elision, high, } \\
\text { middle and low stops, } \\
\text { paragraphi }\end{array}$ & II/III \\
\hline 1093 & $\mathrm{R}$ & $29: 1$ & $27-31$ & $\begin{array}{l}\text { Reformed Documentary } \\
\text { hand }\end{array}$ & $\begin{array}{l}\text { Accents, high, medial } \\
\text { and low stops }\end{array}$ & mid II \\
\hline
\end{tabular}

45 Books that were considered unorthodox would have been produced in the codex format to look orthodox. 
BARKER: Codex, Roll and Libraries

\begin{tabular}{|c|c|c|c|c|c|c|}
\hline 1364 & $\mathrm{R}$ & $22: 3+$ & 33 & $\begin{array}{l}\text { Medium reformed } \\
\text { documentary }\end{array}$ & $\begin{array}{l}\text { Accents, rough } \\
\text { breathings, elision, high, } \\
\text { medial and low stops }\end{array}$ & II/ III \\
\hline 1376 & $\mathrm{R}$ & 32 & c. $49-53$ & $\begin{array}{l}\text { Medium neat reformed } \\
\text { documentary }\end{array}$ & High stops & II/III \\
\hline 1606 & $\mathrm{R}$ & $29: 5$ & c. $46-49$ & $\begin{array}{l}\text { Small to medium } \\
\text { upright informal } \\
\text { reformed documentary }\end{array}$ & Paragraphi, stops & II/III \\
\hline 1607 & $\mathrm{R}$ & $29: 4$ & 40 & $\begin{array}{l}\text { Small to medium neat } \\
\text { reformed documentary }\end{array}$ & High stops & II/III \\
\hline 1608 & $\mathrm{R}$ & $16+$ & c. 32 & $\begin{array}{l}\text { Medium neat reformed } \\
\text { documentary }\end{array}$ & $\begin{array}{l}\text { Double dots, paragraphi, } \\
\text { high and low stops } \\
\text { accents, rough breathings }\end{array}$ & II \\
\hline 1612 & $\mathrm{R}$ & $28: 2$ & c. 40 & $\begin{array}{l}\text { Sloping round reformed } \\
\text { documentary }\end{array}$ & Paragraphi, high stops & III \\
\hline
\end{tabular}

Table 2: Contemporary New Testament Books

\begin{tabular}{|c|c|c|c|c|c|c|c|}
\hline $\begin{array}{l}\text { Siglum } \\
\text { (P.Oxy. } \\
\text { unless } \\
\text { stated) }\end{array}$ & $\begin{array}{c}\text { Aland } \\
\text { no }\end{array}$ & $\begin{array}{l}\text { Codex } \\
\text { / Roll }\end{array}$ & $\begin{array}{l}\text { Size cm } \\
(\mathrm{H} \times \mathrm{W})\end{array}$ & $\begin{array}{c}\text { Lines } \\
\text { per } \\
\text { page }\end{array}$ & Hand & Punctuation & Date \\
\hline 2 & $\mathrm{P} 1$ & $\mathrm{C}$ & $25 \times 12$ & $\begin{array}{c}\text { c. } 37- \\
38\end{array}$ & $\begin{array}{l}\text { Upright neat reformed } \\
\text { documentary hand }\end{array}$ & $\begin{array}{l}\text { Stops, rough } \\
\text { breathings }\end{array}$ & III \\
\hline $\begin{array}{c}208+ \\
1781\end{array}$ & P5 & $\mathrm{C}$ & $25 \times 13$ & 27 & documentary hand & $\begin{array}{l}\text { Blank spaces, } \\
\text { rough breathings }\end{array}$ & Early III \\
\hline 402 & P9 & $\mathrm{C}$ & $15 \times 11$ & 16 & $\begin{array}{l}\text { Carelessly written, } \\
\text { crude and irregular }\end{array}$ & $\begin{array}{l}\text { Blank spaces } \\
\text { rough breathings }\end{array}$ & III \\
\hline $\begin{array}{l}657 / \mathrm{PS} \\
\text { I } 1292\end{array}$ & P13 & $\begin{array}{l}\text { On back } \\
\text { of a roll }\end{array}$ & $?$ & $\begin{array}{l}\text { c. } 23- \\
27\end{array}$ & $\begin{array}{l}\text { Reformed documentary } \\
\text { irregular }\end{array}$ & $\begin{array}{l}\text { Single and } \\
\text { double points }\end{array}$ & III \\
\hline $1008 / 9$ & $\mathrm{P} 15 / 16$ & $\mathrm{C}$ & $26 \times 18$ & $\begin{array}{c}\text { c. } 37- \\
38\end{array}$ & Reformed documentary & $\begin{array}{l}\text { Blank spaces, } \\
\text { rough breathing, } \\
\text { high stops? }\end{array}$ & Late III \\
\hline 1078 & P17 & $\mathrm{C}$ & $25 \times 19$ & 16 & Reformed documentary & $\begin{array}{l}\text { Rough breathing, } \\
\text { double dots, } \\
\text { medial stops }\end{array}$ & Late III \\
\hline 1079 & P18 & $\begin{array}{l}\mathrm{C}-\mathrm{On} \\
\text { back of } \\
\text { a roll of } \\
\text { Exodus }\end{array}$ & $?$ & $?$ & Untrained hand & $\begin{array}{l}\text { High and medial } \\
\text { stops }\end{array}$ & III \\
\hline $\begin{array}{l}\text { PSI. } \\
1165\end{array}$ & & $\mathrm{C}$ & $25 \times 16$ & & Reformed documentary & & Early III \\
\hline 1171 & $\mathrm{P} 20$ & $\mathrm{C}$ & $17 \times 12$ & 25 & $\begin{array}{l}\text { Semi neat reformed } \\
\text { documentary }\end{array}$ & ----- & Late III \\
\hline 1228 & $\mathrm{P} 22$ & $\mathrm{R}$ & 30 & $47-48$ & $\begin{array}{l}\text { Round informal } \\
\text { medium reformed } \\
\text { documentary }\end{array}$ & ------ & Mid III \\
\hline 1229 & $\mathrm{P} 23$ & $\mathrm{C}$ & $21 \times 12$ & 27 & $\begin{array}{l}\text { Neat reformed } \\
\text { documentary }\end{array}$ & Medial stop & $\begin{array}{l}\text { Late } \\
\text { II/III }\end{array}$ \\
\hline
\end{tabular}




\begin{tabular}{|c|c|c|c|c|c|c|c|}
\hline 1230 & $\mathrm{P} 24$ & $\mathrm{C}$ & $28 \times 19$ & $43-45$ & $\begin{array}{l}\text { Medium size, hurried } \\
\text { cursive }\end{array}$ & ----------- & Late III \\
\hline 1355 & $\mathrm{P} 27$ & $\mathrm{C}$ & $25 \times 13$ & 43 & $\begin{array}{l}\text { Small neat reformed } \\
\text { documentary }\end{array}$ & Paragraphi & III \\
\hline 1596 & P28 & $\mathrm{C}$ & $20 \times 13$ & c. 26 & $\begin{array}{l}\text { Medium size, } \\
\text { documentary }\end{array}$ & $\begin{array}{l}\text { High stop, blank } \\
\text { space }\end{array}$ & Late III \\
\hline 1597 & P29 & $\mathrm{C}$ & $27 \times 17$ & $38-41$ & Large size documentary & ----------- & Early III \\
\hline 1598 & $\mathrm{P} 30$ & $\mathrm{C}$ & $26 \times 16$ & 40 & $\begin{array}{l}\text { Large formal heavy } \\
\text { round capitals }\end{array}$ & ----------- & Early III \\
\hline 1780 & P39 & $\mathrm{C}$ & $26 \times 16$ & c. 25 & Large calligraphic & Blank space & III \\
\hline 2383 & P69 & $\mathrm{C}$ & $25 \times 15$ & $?$ & $\begin{array}{l}\text { Moderate size, good } \\
\text { documentary hand }\end{array}$ & ----------- & III \\
\hline 2384 & P70 & $\mathrm{C}$ & $25 \times 15$ & $\begin{array}{l}\text { c. } 28- \\
29\end{array}$ & $\begin{array}{l}\text { Medium to large } \\
\text { upright, documentary }\end{array}$ & ----------- & Late III \\
\hline $\begin{array}{c}2683 / 4 \\
405\end{array}$ & P77 & $\mathrm{C}$ & $16 \times 11$ & c. 20 & $\begin{array}{l}\text { Small neat upright } \\
\text { reformed documentary }\end{array}$ & $\begin{array}{l}\text { Middle stop, } \\
\text { paragraphi, } \\
\text { rough breathing, } \\
\text { blank space }\end{array}$ & $\begin{array}{l}\text { Late } \\
\text { II/III }\end{array}$ \\
\hline 3523 & & $\mathrm{C}$ & $16 \times 12$ & 24 & $\begin{array}{l}\text { Small well formed neat } \\
\text { cursive reformed } \\
\text { documentary }\end{array}$ & $\begin{array}{l}\text { Blank space, } \\
\text { projection into } \\
\text { margin }\end{array}$ & II \\
\hline 4401 & $\mathrm{P} 101$ & $\mathrm{C}$ & $25 \times 10$ & $\begin{array}{l}\text { c. } 32- \\
33\end{array}$ & $\begin{array}{l}\text { Medium competent } \\
\text { semi neat cursive } \\
\text { reformed documentary }\end{array}$ & ----------- & III \\
\hline 4403 & $\mathrm{P} 103$ & $\mathrm{C}$ & $16 \times 11$ & $\begin{array}{l}\text { c. } 19- \\
20\end{array}$ & $\begin{array}{l}\text { Small elegant neat } \\
\text { upright reformed } \\
\text { documentary }\end{array}$ & Medial stop & $\begin{array}{l}\text { Late } \\
\text { II/III }\end{array}$ \\
\hline 4404 & $\mathrm{P} 104$ & $\mathrm{C}$ & $25 \times 14$ & c. 31 & $\begin{array}{l}\text { Small neat and carefully } \\
\text { written cursive } \\
\text { reformed documentary }\end{array}$ & ----------- & II \\
\hline 4445 & P106 & $\mathrm{C}$ & $\begin{array}{l}23 x \\
12: 5\end{array}$ & c. 36 & $\begin{array}{l}\text { Medium semi neat } \\
\text { upright reformed } \\
\text { documentary }\end{array}$ & ----------- & III \\
\hline 4446 & P107 & $\mathrm{C}$ & $?$ & c. 33 & $\begin{array}{l}\text { Small semi neat } \\
\text { reformed documentary }\end{array}$ & ------------ & III \\
\hline 4447 & P108 & $\mathrm{C}$ & $\begin{array}{c}18: 5 \mathrm{x} \\
14: 5\end{array}$ & c. 23 & $\begin{array}{l}\text { Medium neat and } \\
\text { elegant, upright } \\
\text { reformed documentary }\end{array}$ & ------------- & $\mathrm{II} / \mathrm{III}$ \\
\hline 4448 & P109 & $\mathrm{C}$ & $24 \times 12$ & c. 26 & $\begin{array}{l}\text { Medium cursive } \\
\text { reformed documentary }\end{array}$ & ------------ & II \\
\hline 4495 & P111 & $\mathrm{C}$ & $?$ & $\begin{array}{l}\text { c. } 21- \\
22\end{array}$ & $\begin{array}{l}\text { Small semi neat upright } \\
\text { reformed documentary }\end{array}$ & 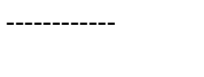 & Early III \\
\hline 4497 & P113 & $\mathrm{C}$ & $?$ & c. 35 & $\begin{array}{l}\text { Small semi neat upright } \\
\text { reformed documentary }\end{array}$ & $\begin{array}{l}\text { Rough } \\
\text { breathings, high } \\
\text { stops }\end{array}$ & III \\
\hline 4498 & P114 & $\mathrm{C}$ & $25 \times 15$ & c. 27 & $\begin{array}{l}\text { Small semi neat cursive } \\
\text { reformed documentary }\end{array}$ & ------------ & III \\
\hline
\end{tabular}


BARKER: Codex, Roll and Libraries

Table 3: Second and Third Century A.D. Secular Codices from Oxyrhynchus

Sigla

P.Oxy. 697

PRIM 1:15

P.Oxy. 2517

P.Oxy. 3157

P.Oxy. 3704

P.Oxy. 2537

P.Oxy 2890

P.Oxy. 3321

P.Oxy. 3708

P.Oxy. 3843

P.Oxy. 4022

P.Oxy 4310

PSI 1.99

PSI 2:153

PSI 14. 1383

PSI 2:128

PSI 2. 140

P.Oxy. 873

P.Oxy. 763

P.Oxy. 2647

P.Oxy. 2168

P.Oxy. 2211

P.Oxy. 2216

PSI 14:1395

P.Oxy. 459

P.Oxy. 538

P.Oxy. 542

P.Oxy. 548

P.Oxy. 553

P.Oxy. 781

P.Oxy. 782

P.Oxy. 955

PSI 7:746

\begin{tabular}{|c|c|}
\hline Content & Date \\
\hline Xenophon, Cyropaedia & II \\
\hline Medical Catechism & II \\
\hline Lexicon to Homer & II \\
\hline Plato, Republic & II \\
\hline Text with musical notation & II \\
\hline Lysias Hypotheses & $\mathrm{II} / \mathrm{III}$ \\
\hline Aeschines Socraticus, Miltiades & $\mathrm{II} / \mathrm{III}$ \\
\hline Euripides & $\mathrm{II} / \mathrm{III}$ \\
\hline Treatise on rhetoric & $\mathrm{II} / \mathrm{III}$ \\
\hline Demosthenes & $\mathrm{II} / \mathrm{III}$ \\
\hline Menander & $\mathrm{II} / \mathrm{III}$ \\
\hline Demosthenes & $\mathrm{II} / \mathrm{III}$ \\
\hline Menander & $\mathrm{II} / \mathrm{III}$ \\
\hline Oratory & $\mathrm{II} / \mathrm{III}$ \\
\hline Hesiod & $\mathrm{II} / \mathrm{III}$ \\
\hline Historical or rhetorical work & III \\
\hline Homer Iliad & III \\
\hline Hesiod, Theogony & III \\
\hline Homer & III \\
\hline Hesiod Theogony & III \\
\hline Callimachus Aetia & III ? \\
\hline Callimachus Aeita & III \\
\hline Callimachus Hecala & III \\
\hline Demosthenes & III \\
\hline Demosthenes, Contra Aristocratem & III \\
\hline Homer Iliad & III \\
\hline Homer Iliad & III \\
\hline Homer Iliad & III \\
\hline Homer Iliad & III \\
\hline Homer Odyssey & III \\
\hline Homer Odyssey & III \\
\hline Homer Odyssey & III \\
\hline Homer Iliad & III \\
\hline
\end{tabular}




\begin{tabular}{|c|c|c|}
\hline PSI 10. 1168 & Homer Iliad & III \\
\hline PSI 10. 1169 & Homer Iliad & III \\
\hline P.Cairo inv 47268 & Homer Iliad & III \\
\hline PRIM 1:10 & Plato, Republic & III \\
\hline P.Ryl. 3. 498 & New Comedy & III \\
\hline PSI 3:158 & Treatise on the Planets & III \\
\hline PSI 2. 147 & Pindar & III \\
\hline PSI 2145 & Pindar? & III \\
\hline P.Oxy. 4476 & Astrology & III \\
\hline P.Oxy. 4635 & Homer & III \\
\hline P.Oxy. 2537 & Hypothesis of Lysias' Speeches & III \\
\hline P.Oxy. 4049 & Aeschines Orator & III \\
\hline P.Oxy. 4029 & Aeschines Orator & III \\
\hline P.Oxy. 2890 & Aeschines Socracticus & $\mathrm{II} / \mathrm{II}$ \\
\hline P.Oxy. 4503 & Anubion & III \\
\hline PSI 6720 & Aristophanes & III \\
\hline $\begin{array}{l}\text { W. Brasher in Ancient Magic in the } \\
\text { Greek World 1955, 229-231 n.6 }\end{array}$ & Astrampsychus & III \\
\hline PSI 14 & Demosthenes & III \\
\hline P.Oxy. 4323 & Demosthenes & III \\
\hline P.Oxy. 4326 & Demosthenes & III \\
\hline P.Oxy. 877 & Euripides & III \\
\hline C. Edgar, ASAE 26 (1926) 203 & Homer & III \\
\hline P.Oxy.3551 & Theocritus & III \\
\hline P.Oxy. 3450 & Thucydides & III \\
\hline P.Oxy. 214 & Alexandrian Epic? & III \\
\hline P.Oxy. 3709 & Scholia? & III \\
\hline P.Oxy. 3299 & Planetry Tables & III \\
\hline P.Sorb. I 8 & $\begin{array}{l}\text { Philology, lexicography, Greek and Latin } \\
\text { vocabulary }\end{array}$ & III \\
\hline
\end{tabular}

